\title{
Population Growth and its Impact on Natural Resources: A Study of Uttarakhand State
}

\author{
Mridula Sharma J.S.H Mahavidlaya Amroha (J.P. Nagar)
}

\begin{abstract}
Present paper is about growing population in Uttarakhand and its impact on natural resources. According to Gandhi ji,' There is enough for everybody's need and not for anybody's greed. The geographically informed person understand that a "resource" is a cultural concept. A resource is any physical material constituting part of earth that people need and value. Natural materials become resources when humans value them. The uses and values of resources change from culture to culture and from time to time. Resources are spatially distributed varying in quantity and quality. Some resources are finite. While others can be replenished at varying rates. However, humans need to balance short - term rates of use against long-term availability.

Mr. Thomas Robert Malthus ( The first economist to propose a systematic theory of population) proposes the principle that populations grow exponentially while food production grow at an arithmetic rate.

while food output was likely to increase in a series of twenty five year intervals in the arithmetic progression $1,2,3,4,5,6,7,8,9$,population was capable of increasing in geometric progression 1,2,4,8,16,32,64,128,256, and so forth. This scenario of arithmetic food growth with simultaneous geometric human population growth predicted future when humans would have no resources to survive on.
\end{abstract}

Key Words: Population, Natural Resources, Forest, Water, Land use, Growth, Density, Urbanization, Agriculture, Barren Land, Temperature, Environment

\section{INTRODUCTION}

Human population growth is the major reason why there is loss of natural resources. These natural resources are saving our needs well by providing food, shelter, clothing and energy. Taking these for granted results in environmental consequences that will affect all life forms of this state.Human population is growing rapidly and for this population we need more space to live, more food to feed, and drinking water also. These are the basic needs to survive, but for better life they need good infrastructure and other facilities like education, hospitals, employment. For growing population we need space so we are cutting forests for infrastructure , to provide food we are growing more food grain by using more and more scientific method and the result is the land of uttarakhand state is loosing its fertility.Drinking water is the most burning issue in present and for future also. Uttarakhand state is the source of India's most rivers but itself, this state is also suffering from contaminated water problem. People are suffering from drought problem also. The Himalayan is dotted with 12 rivers, out of 18 major rivers of the country. Hundreds of small rivulets and thousands of streams make the Himalaya as "Water bank of Asia". This constitue 42\% pf the total of the country .It is ironical that these rivers have not been of any use to the local resident, except for the minor utilities in the form of watermill, occasional irrigation, not exceeding $2 \%$ of the total potential use. $72 \%$ women and $14 \%$ children have to bear the responsibility of carrying potable water. The average $60 \%$ women have to walk ${ }_{/ 2}^{1} \mathrm{~km}$. While $10 \%$ of them walk $4 \mathrm{~km}$ for fetching water.

Population growth is ruining the balance of Himalayan state. To feed this population farmers are cutting the trees for more agriculture land. Deforestation is inviting the soil erosion and flood. This Himalayan state is very complicated by surface like Uttarakhand has 13 districts, 3 districts are plain and 10 districts are hilly. So the population distribution is also very complicated. Hilly districts like Uttarakashi , Chamoli , Rudraprayag , Pithoragarh and Bageshwar etc are low density districts. Haridwar, Nainital, Tanakpur , Dehradun etc are high density districts. That' $\mathrm{s}$ why population distribution is also a problem with population growth

\section{STUDY AREA:}

Uttarakhand was formed on $9^{\text {th }}$ November 2000. Uttarakhand is a $18^{\text {th }}$ biggest state in India with an area of about 53,483sq.km. It borders Tibet to the North, Nepal to the east, the plain of Uttar Pradesh to the west Himachal Pradesh to the north west. It comprises of two main hilly region Garhwal and Kumaon which is 
connected by the flatlands called the Tarai in the base. Uttarakhand extends from $28^{\prime} 43^{\prime} \mathrm{N}$ to $31^{\prime} 27^{\prime} \mathrm{N}$ longitude $77^{\prime} 4^{\prime} \mathrm{E}$ to $81^{\prime} 01^{\prime} \mathrm{E}$ latitude.

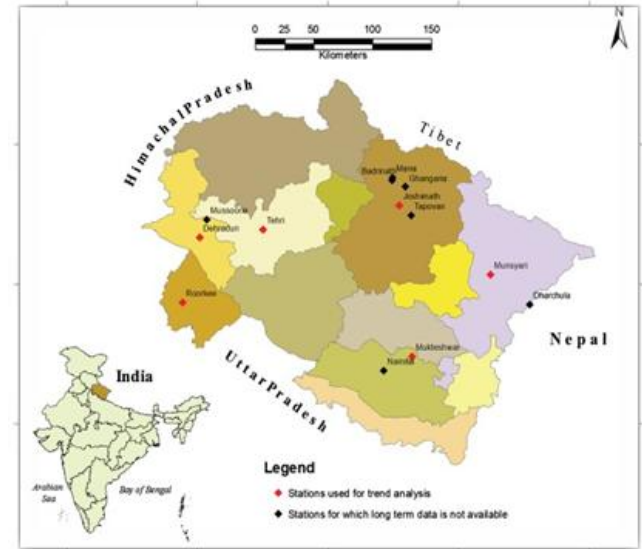

The native of the state are generally called Uttarakhandi or more specially either Garhwali or Kumaoni depending on their place of origin .According to the 2011 Census of India. Uttarakhand has population of $10,116,752$, making it the 19the most populous state in India It is blessed with rare bio-diversity, inter -alia , 175 rare species of aromatic \& medicinal plants are found in the state. It has almost all majore climate zone , making it amenable to a variety of commercial opportunities in horticulture, floriculture and agriculture.It has a vast tourism potential in adventure leisure and eco- tourism.

\section{METHODOLOGY:}

The present report is primarily based on desk study, involving compilation and analyses of information and data from official documents, research papers/ reports, media reports and articles.This report analyzes Uttarakhand 's current development pattern in terms of equity and sustainability . Here in this report we will discuss about the population growth of uttarakhand and its impact .As we know that Uttarakhand is a Natural state a big part of population is depend on Natural Resources for survive . Here in our report we can see that uttatarakhand's population is increasing by leaps and bounds and Nature is suffering from that situation .By the year wise data of population we will compare population growth districtwise.

\section{RESULTS AND DISCUSSIONS}

Uttarakhand has a multipical population spread across two recognized geocultural region :the Gahrwal , which corresponds roughly to the northwestern half of the state, and the Kumaun, which spans the southeast. As we can see in datas that the growth rate of population in Uttarakhand state is not equal like the hill districts have shown very low growth rates. As we can see that the population of hilly areas live a very hard and different life they full dependent on nature. Population of uttarakhand state is divided in to types of surface first one is hilly areas tough to survive and the second is foot hill area which is totally plane comparatively no of people are more here then hilly areas .Hilly area population has limited time period to work here in winters from October to march people cannot do any work here they survive only on their summer savings .Migration towards plane districts is the result of hard condition of their places for searching occupations people migrate from their native place.That is why population of foot hills districts of uttarakhand is growing rapidly than hilly districts .

\section{Trend of Population Growth}

According 2011 census of India, Uttarakhand 's population has reached approximately 1.01 crore with an increase of 19.17 percent from the past decade.Uttarakhand feeds approximately $0.84 \%$ of india 's total population. Uttarakhand is a newest state in India but after that it is on $19^{\text {th }}$ position , population wise . population of this state is $10,116,752$, according to the 2011 census and the density as pr $\mathrm{km}$. is 189 , sex ratio is 963. As we can see in the fig. one there is a lot of difference between 1951 to 2001 , in 1951 population growth rate is 12.67 in this age uttarakhand was not an independent state it was the part of uttar Pradesh due to that condition there was no better facielities and opportunities. We can see in 1951 there were very cruecial condition in 


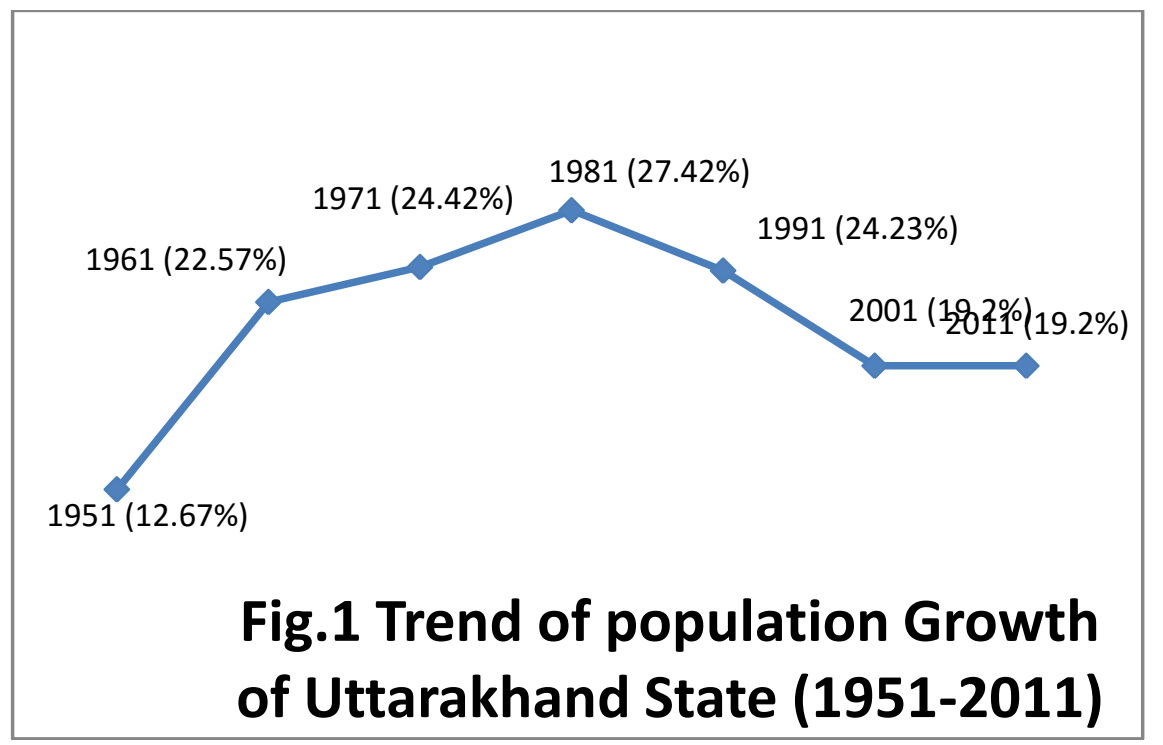

Hilly areas the growth rate of population was very low only $12.67 \%$ during this year 1951 there were no hospitals specialy in hilly areas pregnant ladies and sick peoples were mostly depends on local old types of methods to cure but slowly the death rate decreased during year 1961 because of that population growth rate increased in the year1961 the population growth rate was $22.57 \%$ and sudden in the 1971 the growth rate was $24.42 \%$ or $27.42 \%$.population of Uttarakhand state suddenly stabled at the digit of $24.23 \%$ due to some natural and manmade conditions the population of uttarakhand state decreased in year 1991 and 2001 the growth rate was only $19.2 \%$ which is very low in compare of year 1971 and 1981 . By this fig. We only trying to show that the population of uttarakhand state is not consistent during past years.

If we compared the stare population data with the country we can see that the density of population pr sq. Km. Is about 189 and fairly below the national average. The state has a growth rate of about $19.2 \%$ which slightly exceeds the national growth rate of about 175 . The population of state is rising considerably due to rapid efforts towards development and progress. The literacy rate in the state is about $80 \%$ a figured that has improved in the last few years due to the consistent efforts of the government. The sex ratio in uttarakhand exeeds the national average by 20 points.

\section{UTTARAKHAND URBAN POPULATION}

The history gives the evidence of urbanization in Uttarakhanad.Towns were originally rural settlements converted in to towns in the later stage The basic reason behind this is the tourism because the state is the heart of famous pilgrimage. Originally towns of uttarakhand state were the stoppage centres of the pilgrims during Yatra Season slowly because of number of commercial activities, these stoppage places developed in to the small towns small to medium town.As we can see in the fig no 2 population of cities during 1991,2001 and 2011 according to the census is increasing rapidly in year 1991 and 2001 population increased but in year 2011 it had some stability not because population awareness just because development in hills better medical facilities are providing there by the government .

Fig 2: The population of the districts in the State of Uttarakhand (Uttaranchal).

\begin{tabular}{|c|c|c|c|c|}
\hline S.N & Districts & $\begin{array}{c}\text { Population } \\
\text { Census } \\
1991\end{array}$ & $\begin{array}{c}\text { Population } \\
\text { Census } \\
2001\end{array}$ & $\begin{array}{c}\text { Population } \\
\text { Census } \\
2011\end{array}$ \\
\hline 1 & Almora & 610,500 & 632,866 & 622,506 \\
\hline 2 & Bageshwar & 226,200 & 247,163 & 259,898 \\
\hline 3 & Chamoli & 325,311 & 370,359 & 391,605 \\
\hline 4 & Champawat & 190,900 & 224,542 & 259,648 \\
\hline 5 & Dehradun & $1,025,679$ & $1,282,143$ & $1,696,694$ \\
\hline 6 & Garhwal (Pauri & 670,800 & 697,078 & 687,271 \\
\hline 7 & Garhwal) & & & \\
\hline & Hardwar & $1,124,500$ & $1,447,187$ & $1,890,422$ \\
\hline
\end{tabular}




\begin{tabular}{|l|l|r|r|r|}
\hline \multirow{2}{*}{ S.N } & \multicolumn{1}{|c|}{ Districts } & $\begin{array}{c}\text { Population } \\
\text { Census } \\
1991\end{array}$ & $\begin{array}{c}\text { Population } \\
\text { Census }\end{array}$ & $\begin{array}{c}\text { Population } \\
\text { Census } \\
2001\end{array}$ \\
\hline 8 & Nainital & 574,800 & 762,909 & 954,605 \\
\hline 9 & Pithoragarh & 416,647 & 462,289 & 483,439 \\
\hline 10 & \multicolumn{1}{|c|}{ Rudraprayag } & 200,493 & 227,439 & 242,285 \\
\hline 11 & Tehri Garhwal & 520,214 & 604,747 & 618,931 \\
\hline 12 & Udham Singh Nagar & 924,900 & $1,235,614$ & $1,648,902$ \\
\hline 13 & Uttarkashi & 239,709 & 295,013 & 330,086 \\
& & & & \\
\hline Total & & & & \\
\hline
\end{tabular}

As we can see in fig 2 that urbanization is increasing day by day now population is increasing in hilly areas also. According to the surface we found that there are 13 districts in the state , 3 are plain districts and the 10 are hill districts .Geographically the state can broadly be divided into three zones, namely-UPPER

HILLS -Uttarakashi, Chamoli, Rudraprayag, Pithoragarh and Bageshwar. MIDDLE HILLS - Tehri Garhwal , Garhwal, Almora and Champawat, the hill regions of Nainital and Chakrata tehsill of Dehradun .

FOOT HILLS - The remaining area of Dehradun ,Haridwar, Udham Singh Nagar and the remaining area of Nainital .

The population of the districts in Uttarakhand varies considerably. Four of the 13 districts, namely Dehradun, Haridwar, Udham singh Nagar and Nainital account for $61.5 \%$ of the state's total population. On adding Tehri Garhwal, Pauri Garhwal and Almora, this accounts for nearly 81\%. This clearly shows that the concentration of population is quite high in the mid and foothills as compared to the remaining six districts of high hills. The density of population according to the 2011 census is 189 person per squqre kilometre, higher than the 2001 census figure of 150 . District- wise , there is enormous variation in the density of population with Haridwar, Udham Singh Nagar and Dehradun having in the density of 817, 648 and 550 person per square km respectively; while on the other hand there are districts like Uttarkashi,Chamoli and Pithoragarh the population density is quite low with average of 41,49 and 69 persons per square $\mathrm{km}$.

Uttarakhand is a predominantly rural state with 16,826 rural settlements of which 12,699 or $81 \%$ have a population of less than 500. In most of the districts , more than 75-85\% of rural settlements have a population of less than 500. Only $17 \%$ of the rural settlements have a population ranging between 500-1999and the villages with population of 2000or more are very rare $(2.7 \%)$. The small size of settlements and their widespread distribution is a formidable challenge for service delivery in the state of Uttarakhand with sach a high percentage of small and scattered hamlets mainly in the tough geographic condition .

\section{NATURAL RESOURCES:}

Uttarakhand has a total area of $53.489 \mathrm{~km}$ of which $86 \%$ is mountainious and $65 \%$ is covered by forest Uttarakhand state is well endowed with forest and water resources more than 12,000 glaciers and 8 major rivers catchments act as the lifeline for the entire hydrogical system of Indo-Gangetic plain.Uttarakhand state is endowed with a unique and diverse range of biodiversity.From the snowbound peaks of the Himalaya as to the moist Alpine scrub, sub Alpine forests, dry- temperate and the moist - temperate forests to moist deciduous forests, the state possesses a wide biodiversity that inn return nurtures a large multiplicity of floral and fauna forms. Uttarakhand state is a undoubtedly very rich state in natural resources point of view but besides of this hilly area of uttarakhand state is full of difficulties like human only can survive here in natural ways specialy in high altitude areas .Diversity in population in uttarakhand state is just because of the wide biodiversity.

\section{FOREST RESOURCES}

Most of the northern part of the state is covered by high Himalayan peaks and glaciers. Uttarakhand lies on the southern slope of the Himalaya range,and the climate and vegetation vary greatly with elevation, from glaciers at the highest elevation to subtropical forest at lower elevation.The highest elevation are covered by ice and bare rock. Below them, between 3,000 and 5,000 metres are the Western Himalaya alpine shrub and meadows. The temprate western Himalaaya subline conifer forest grow just below the tree line. At 3,000 to 2,600 metres elevation they transition to the temprate western Himalayan broadleaf forests. Which lie in a belt 
from 2,600 to 1.500 metres elevation. Below 1,500 metres elevation lie the Himalayan subtropical pine forests. The Upper Gangetic plains moist deciduous forests and the drier Terai Duar Savanna and grasslands cover the lowlands along the Uttar Pradesh border in a belt locally known as Bhabar. These lowland forests have mostly been cleared for agriculture, but a few pockets remain

The overpopulation thesis- Concern with population pressure is ubiquitous in literature on defodation, soil degradation, loss of biodiversity, threat to future pease and stability, food scarcities, global warming and underdevelopment. According to Wilson, "the raging monster upon the land is overpopulation growth. In its presence sustainability is but a fragile theoretical construct".

A policy document from the World Bank affirms that,"the causes of environmental degradation are as varied as its manifestations. But at the heart of the problem is the rapid rate of population growth in Uttarakhand state specially in the foothill districts .According to the 2001 census population growth rate of Uttarakhand state was $19.2 \%$, total geographical area was 53483 in which total forest land was 23938, dense forest 19023, open forest 4915, percentage of forest area to geographical area was 44.76. Comparatively forest area is decreasing day by day. Due to faster population growth in forest areas naturally available forest resources in a sustainable manner are becoming inadequate for their basic livelihood. In the hilly areas many tribal are giving up their traditional livelihood and taking up farming and cattle rearing in the forest areas causing unrepairable damage to forests. The erstwhile protectors of forests are slowly turning into bane of forests and its wildlife.

Government should devise schemes to avert this process and save the dwindling forest area and its flora and fauna. People of uttarakhand have extraordinary understanding of forest flora and fauna which can be productively utilized.Population growth and its needs are increasing, for their nessesseties to livelihood they are swaping the forest areas .Now due to this blind game humen are inviting a big disaster forests clenched the mountainious soil they have given power to the Himalayan region to keep stable but the blindly cutting of forest Himalaya is loosing its stability. Actually, population is not a problem, problem is the number of people are increasing compare of natural resources like we have space only for few but we having a lot .

\section{AGRICULTURE AND SETTLEMENTS}

Most of the area of state Uttarakhand is under forests and wastelands thus leaving only a small amount of land i.e. 7.41 lakh ha (about 14\%) (LUS2009-10) for cultivation out of the total reported area of 56.72 lakh ha.Increasing population and consequent growing demand for food and services have imposed severe strain on the natural resource, especially on land use. It occupies pivotal position in the economic and social life. When the uttarakhand make a new state it has been cut about 35483 sq. km. land from the Uttar Pradesh 2000.That time the population of uttarakhand state was majorly depend on agriculture and forestry . The rich natural resources are always be a good guardian for uttarakhand people. The main occupation of uttarakhand population is agriculture and tourism .Uttarakhand is primarily an agriculture state although its share the country's total rea and production is very small. The contribution of agriculture to the state's domestic product is about 22.4 per cent and the pupolation dependent on agriculture for their livelihood is about 75-85 percent respectively. For instance, the productivity of wheat in the hills is 13.2quintals/hectare, while in the plain it is 30.45quintals/ hectare .For rice figures stand at 12.36 quintals/hectare in the hills and 27.49 quintals/hectares in the plains(Uttarakhand State Planning Commission, 2007). This highlights the need for separate approaches for agricultural development in the hills and plain areas of the state.

According to the Lyndon B. Jonson-"The hungry world cannot be fed until and unless the growth its resources and the growth of its population come in to balance. Each man and woman and each nation -must make decisions of conscience and policy in the face of this great problem." population growth is a curse for any state or country. increasing population not only wants more place to live but also more food, more condition to develop livelihood. According to a survey trees have been removed from 90 lack hac land for agriculture land in $20^{\text {th }}$ century . increasing food needs of population is pressuring the farmer to provide more food , to grow more food grains farmer used lots of fertilizers and repeat crops and the result come out that the agriculture land has lost its fertility.

According to the Henry W. Kendall-"If we do not voluntarily bring population growth under control in the next one or two decades, The nature will do it for us in the most brutal way, Whether we like it or not " to prove these words we can remind the disaster in the year 2013 ,Uttarakhand suffered from a majore catastrophic natural disaster in the form of huge and deadly cloudbursts, causing flash floods in River Ganga . Today, Uttarakhand flash floods are considered the most disastrous floods in the history of India.

(a)

\section{Barren Land}

During the last few decades there has been phenomenal increase in population in state uttarakhand .Even though uttarakhand recognized the problem of rapid population growth soon after year 1961 by the rate of 
$22.57 \%$, it has limited success in controlling its growth rate in year 1991. The consequences of such population growth for uttarakhand span three areas; changes in land use, increase in toxic chemical released to the environment and depletion of natural resource.As population increases, this expanded growth begins to distort our environment, leaving what scientist call an ecological footprint. In Uttarakhand most of the people doing farming as main profession, in their fields they produce vegetables, grains, pulses. Mountainous pulses are very much famous for its medicated benefits.The main source to irrigate sown area being rain fed (in hilly areas)and the percentage of irrigated area in the foothills ,by underground water and artificial supply like pump and all . Although, due to its atmosphere soil of Uttarakhand state is full of moisture ,so the crops can survive with low rain shed but since last few year the uncertainty of rain shed is developing dryness in soil cause of that peoples are facing the drought situation, those are very crucial signs given by nature .

Barren land problem in foothill areas we can see in uttarakhand state , urbanization in metropolitan cities like Dehradoon ,Haridwar, Rishikesh, Tanakpur areas facing the barren land problem . Reason of this situation is the demand and supply, agriculture land is not capable to fulfil population demands .Cause of more demands of food supply and more profit farmer is using the agriculture land repeatedly, this repetitive behaviour towards agriculture land is not suitable for land fertility .That's why land fertility is decreasing day by day and most of the part of agriculture land is converted in barren land .

According to the Franklin D. Roosevelt "A nation that destroys its soils destroys itself. Forests are the lungs of our land, purifying the air and giving fresh strength to our people." Uttarakhand state is now suffering from barren land problem now nature gave it so many gifts to consume moisture, Uttarakhand glaciers are the water tower in $21^{\text {st }}$ century and cautions that this does not only refer to glaciers, but to forests. Oak and Buransh type trees has the power to consume moisture but the continuous exploitation is decreasing their quantity and that's why temperature of hilly areas is increasing day by day.

\section{CONCLUSIONS}

Uttarakhand state needs to implement the indigenous development vision emphasized by the local people during statehood agitation. The first priority of this state must be expand forest cover area in a manner that enables livelihood to grow. local communities must be custodians managers of their environmental resources . Uttarakhand population should be understand about the delicacy of their state, hill areas are become disaster plateform now the cities and villages which are situated on the bank of Ganga ,Yamuna, Alaknanda rivers in Uttarakhand state we can see that lots of hotels and houses and resorts have been developed there. According to the uttarakhand environmental department " This state is one of the dangerous area in all over world. "Earth quakes, land sliding and floods are common here. Here we can say that, "Uttarakhand state is a nature's bucket, if we'll not do respect its privacy it'll destroy us by itself."

Population growth is a monster, who is swallowing all natural resources. Local must be aware about the delicacy of their state, they should do some work for population management. As per details from census 2011 Uttarakhand has population of 1.01 crores, an increase from figure of 84.89 lakh in 2001 census.Total population of Uttarakhand as per 2011 census is $10,116,752$, in year 2001 ,total population was $8,489,349$.The last census of Uttarakhand was done in 2011 and next would be in 2021.Population growth in Uttarakhand is quite differential in hilly areas and in foothill areas.We are not saying that urbanization is not good, it is but till then, when they respect each other's space.

\section{RECOMMENDATIONS:}

Natural resources are important determinants of economic property. But ultimately prosperity is determined by how the resources are harnessed by the people. In India, There are states like Bihar which are very rich in mineral resources. In comparison, Punjab is disadvantageously placed. But Punjab is economically more prosperous. The difference arises partly because of the people in the two situations.

The size of population determines the quantitative aspect. The qualitative aspect, which is more important, is determined by level of education, work culture and the political and social institutions. More people can be an asset. They can also be a liability if they do not have productive efficiency and a commitment to perfection.

Uttarakhand, with richest Himalayan state, with its rich natural resources. About one- third of the people still cannot afford two square meals every-day. The situation calls for sustained efforts to educate our population and more than anything else cultivate a proper cultured in the state. 


\section{REFERENCE}

[1] An Essay on The Principal of Population :Thomas Malthus : 1798.Uttarakhand : Government Portal:NICUttarakhand state unit, Dehradun. Population Data District wise: Website- WWW.CENSUS 2011.co.in.Brief History of Census: GOI ～(2001) Census of India.

[2] "India- General Profile, Landscape Classification and Land use Pattern. National Information Centre (NIC) . Ministry of Environment \& Forest.

[3] Migration: Government of India (2001)Census of India .District wise Population of Uttarakhand(as per census 1991-2001-2011.

[4] Natural Resources Data Management System-27 April16.Water Wise in Uttarakhand : India Environment Portal 19/4/1997

[5] The Hindu:News Paper: Uttarakhand to monitor the state of natural resources - july 6, 2013. Uttarakhand State Planning Commission, 2007

[6] National Bank for Agriculture and Rural Development (under SDC)

[7] Agriculture Profile of Uttarakhand: Usha Tuteja( University of Delhi) January 2013Watershed Management Directorate (wmd) ,Dehradun 